\section{Response to: 'Autoinflammatory disease damage index (ADDI): a possible newborn also in hidradenitis suppurativa daily practice' by Damiani et al}

We thank Dr Damiani et $a l^{1}$ for their interesting letter about the utility of the autoinflammatory disease damage index (ADDI) in patients with hidradenitis suppurativa (HS), as a response to our recently published article 'The development of the autoinflammatory disease damage index'. ${ }^{2}$ It is important to investigate whether the ADDI is also useful for other autoinflammatory diseases. However, we need to consider that the ADDI is developed and will be validated for familial Mediterranean fever, cryopyrin-associated periodic syndromes, tumour necrosis factor receptor-associated periodic fever syndrome and mevalonate kinase deficiency only. The selection of items was based on an intensive literature search and consensus procedure, to make sure all (and only) relevant items for these four diseases were covered. ${ }^{2}$ HS-specific damage, such as disfiguring scars, will not be measured by the ADDI, although this damage might have an important influence on the patients' daily life. ${ }^{3}$ As mentioned in the letter, prospective validation of the ADDI in patients with $\mathrm{HS}$ is essential before it can be used in the daily practice. We are looking forward to these results.

\section{Kim V Annink, ${ }^{1}$ Nienke M ter Haar, ${ }^{2,3}$ Joost Frenkel ${ }^{1}$}

${ }^{1}$ Department of Paediatrics, University Medical Centre Utrecht, Utrecht, The Netherlands

${ }^{2}$ Laboratory for Translational Immunology, University Medical Centre Utrecht, Utrecht, The Netherlands
${ }^{3}$ Department of Paediatric Immunology, University Medical Centre Utrecht, Utrecht, The Netherlands

Correspondence to Professor Joost Frenkel, Wilhelmina Children's Hospital, Room KE 04133 1, Lundlaan 6, PO Box 85090, Utrecht 3508 AB, The Netherlands; j.frenkel@umcutrecht.nl

Contributors The authors wrote the response to the eletter.

Competing interests None declared.

Provenance and peer review Commissioned; internally peer reviewed.

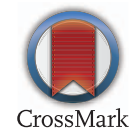

To cite Annink KV, ter Haar NM, Frenkel J. Ann Rheum Dis 2017;76:e26.

Received 14 December 2016

Accepted 17 December 2016

Published Online First 2 January 2017

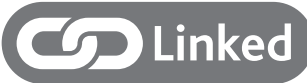

http://dx.doi.org/10.1136/annrheumdis-2016-210901

Ann Rheum Dis 2017;76:e26. doi:10.1136/annrheumdis-2016-210918

REFERENCES

1 Damiani $G$, Valle della $\mathrm{V}$, lannone $\mathrm{M}$, et al. Autoinflammatory disease damage index (ADDI): a possible newborn also in hidradenitis suppurativa daily practice. Ann Rheum Dis 2017;76:e25.

2 Ter Haar NM, Annink KV, Al-Mayouf SM, et al. Development of the autoinflammatory disease damage index (ADDI). Ann Rheum Dis 2017;76:821-30.

3 Dufour DN, Emtestam L, Jemec GB. Hidradenitis suppurativa: a common and burdensome, yet under-recognised, inflammatory skin disease. Postgrad Med J 2014;90:216-21. 